\title{
Promotion of good governance and combating corruption and maladministration: the case of Botswana
}

\author{
MELVIN L M MBAO \\ Professor in Public Law and Legal Philosophy, North West University \\ GG KOMBONI \\ Attorney at law, Botswana
}

\section{INTRODUCTION}

Until fairly recently Botswana was almost universally praised for its excellent record on political governance, exemplified by a relatively functioning multi-party democracy since independence in $1966 .{ }^{1}$ This record on political governance has been underpinned by a generally well-managed economy. According to the United Nations, between the late 1960s and the early 1990s Botswana recorded the highest sustained real GDP growth rate in the world, averaging 6.1 per cent between 1966 and $1991 .^{2}$

Equally important is the fact that although Botswana has had a booming economy which has provided fertile ground for corruption opportunities, the country ranked among the least corrupt countries in the world, and was certainly the least corrupt country in Africa. ${ }^{3}$

In this article, Botswana's responses to the challenges of good governance, corruption and maladministration are critically analysed against benchmarks reflecting international best practice. The first part of the article sets the tone by delineating the concepts of good governance, corruption and maladministration. The essential contours of these terms are unpacked with reference to international and regional perspectives. The second part of the article proceeds to analyse efforts to promote good governance and combat the twin scourges of corruption and bad governance or maladministration. The article concludes that much remains to be done in order to consolidate good

1 Tordoff W Government and Politics in Africa 3rd ed London: Macmillan Press (1997). See Molusti P "Elections and Electoral Experience in Botswana", in Botswana Politics and Society (ed) Edge and Lokorwe (1998) 372.

2 Tordoff (fn 1 above); United Nations, Committee on the Rights of the Child "Initial Report of State Parties, Botswana" CRC/C/51/Add.9, (25 February 2004) 8. See Good K "Corruption and Mismanagement in Botswana: A best case example" (1994) Journal of Modern African Studies 499-521.

3 Transparency International Corruption Perception indexes for 2003, 2004, 2005 and 2006 as accessed on 18 January 2007. 
governance and to strengthen the anti-corruption institution in line with the country's 2016 vision of establishing an open, accountable and democratic nation in which all citizens are free, involved and can contribute meaningfully to development.

\section{THE NOTION OF GOOD GOVERNANCE}

Although there is no universally accepted definition of "governance", the popular usage of the term comprehends how a given country is governed; how the affairs of a state are administered and regulated and how a nation's political system functions in relation to the management or conduct of public affairs. It also embraces how national resources are managed and how relations among the state, citizens and the private sector are regulated.

The World Bank came up with its definition of governance in 1989 in the context of the exercise of political power in relation to the management of a country's affairs. The huge debt crisis, mainly in Central America and to some extent Africa, caused the Bank to take an increased interest in the political and institutional environment before granting credit facilities. The World Bank Report on Africa, 1989 argued that underlying the litany of Africa's developmental problems was a crisis of governance, epitomised by the notion of "failed states" as exemplified by such countries as Somalia, Sierra Leone, Liberia and Zaire (now the Democratic Republic of the Congo). ${ }^{4}$

At the heart of structural adjustment programmes and public sector reforms demanded by the Bank and its sister institution, the International Monetary Fund, was the notion of "good enough governance" or simply "good governance". It is important to point out here that the addition of the qualifiers "good" or "democratic" marked a paradigm shift in the discourse. During the 1960s and 1970s approaches to the subject of governance emphasised the possibility of, and capacity for, exercising power "efficiently", understood in terms of achieving the objectives of the rulers, rather than in terms of the rule of law, accountability, transparency and participation that are characteristic of democracy. In some cases, democracy and governance were treated as inconsistent with the argument that major increases in social demands were overloading democracies. In other cases it was argued that democratic practices made it more difficult to introduce economic, social and political reforms that would affect the interests of powerful groups. ${ }^{6}$ In the result, the older and more restricted conception of governance as efficiency in economic management has evolved into a broader understanding of the way in which leaders exercise power and authority in an effective and inclusive manner to advance the cause of human rights. As the United Nations has correctly observed:

4 World Bank Report, Washington, DC (1989).

5 United Nations, Note by Secretariat "The right to development: Study on existing bilateral and multi-lateral programmes and policies for development partnership." E/CN.4Sub.2/2004/15 8.

6 United Nations Report (fn 5 above) 9-10. See also E/CN.4/Sub2./2004/19 page9. 
"Human rights are inextricably linked with democratic governance. They both require people conscious of their rights and duties, appropriate institutional arrangements, and the existence of a democratic civic culture that applies both to issues of national importance and to those of everyday life. The sense of belonging to a community is nurtured by individual responsibility and by a collective observance of democratic principles. From this perspective, the unrestricted respect and defence of human rights constitutes the foundation of an equitable and participatory society in which everyone helps to achieve the common good, and in which individualism and competition are balanced by social awareness and solidarity." 7

The point to note here is that human rights norms, now authoritatively enshrined in the International Bill of Human Rights, provide a set of performance indicators or standards against which governments and other actors can be held accountable. ${ }^{8}$ As the Office of the United Nations High Commissioner for Human Rights reminds us:

"[G]ood governance promotes human rights in a number of ways. It encourages public participation in government, inclusion in the law-making and policy-making, and accountability of elected and appointed officials. It enables civil society to become actively involved in policy making and leads to the wide representation of societal interests in decision-making. In this manner, disadvantaged groups, including women and minorities, are empowered to defend their rights. The result may be laws and policies that better respect cultural diversity, contribute to the resolution of conflicts and tensions, and address the challenges of inequality and poverty."

In the context of this aritcle, it is important to point out that the law and associated legal institutions provide the framework within which democratic institutions operate and temper democratic rule by ensuring minimum guarantees for human rights and fundamental freedoms. Moreover, "democracy is not synonymous with elections. In addition to elections, democracy relies on transparency, accountability, inclusion and participation in order to protect human rights". ${ }^{10}$ In similar vein, Shelton has perceptively observed that

"in a practical sense democracy, rule of law and respect for human rights are indivisible and interdependent because democracy without human rights and the rule of law is oppression, human rights without democracy and the rule of law is anarchy and the rule of law without democracy and human rights is tyranny". ${ }^{11}$

In this milieu, democracy is now conceived not only as an end in itself but also as a means to political, economic and social rights. Human rights and democratic governance are inextricably linked and mutually reinforcing and share many core principles such as participation, accountability, transparency and responsibility. Indeed, human rights need a conducive and

7 United Nations (fn 5 above) 9.

8 United Nations, Commission on Human Rights "The role of good governance in the promotion of Human Right” Resolution 2000/24. This resolution identifies a set of good governance principles (transparency, accountability, participation and responsiveness.

9 Office of the High Commissioner for Human Rights "Good governance practices for the protection of Human Rights” New York (2007) 9.

10 UN High Commissioner (fn 9 above) 9.

11 UN note by Secretariat E/CN.4.2005/58 page 4. 
enabling environment, in particular appropriate regulations, institutions and procedures framing the action of the state.

Apart from the good governance and human rights perspective, the conditionalities established by international financial institutions for obtaining access to their resources also underscored the indispensability of good governance to economic development in terms of an efficient, open, accountable and audited public service which has the bureaucratic competence to help design and implement appropriate policies and manage whatever public sector there is. It also entails an independent judicial system to uphold the law and resolve disputes arising in a largely free market economy. ${ }^{12}$

The Bretton Wood institutions are not the only ones demanding conformity to international best practice on good governance. Western governments and donor agencies are also increasingly employing the concept of good governance and the benchmarks encapsulated therein in the sphere of development assistance and donor programmes. As the United Nations Secretariat has observed:

"In today's aid climate, it is generally accepted that it is legitimate for donors to require some reassurances when they provide financial or technical assistance; they are accountable to their domestic constituencies and parliaments and need to make sure that the resources they provide are best used." 13

\section{GOOD GOVERNANCE IN AN AFRICAN REGIONAL PERSPECTIVE}

It is instructive to note that the notion of good governance has been included in the objectives and policies of the African Union. Article 3(a) of the Constitutive Act of the African Union, adopted at Lome, Togo in July 2000, provides for the promotion of democratic principles and institutions, popular participation and good governance. Furthermore, one of the key objectives of the New Partnership for African Development (NEPAD) is to promote and protect democracy, good governance and human rights in Africa by establishing or setting clear standards of accountability, transparency and participative governance. In essence, NEPAD endorses democracy and good governance as essential conditions for sustainable development. ${ }^{14}$

Furthermore the African Peer Review Mechanism, though voluntary, is unique in that once a country chooses to sign up to the APRM, it undertakes to pursue a higher standard of democracy, human rights and economic management. It surrenders a small measure of sovereignty to its peers within the APRM movement, though not outside it, and could be subject to unsought

12 Landell Mills, Seragelid "Governance and the external factor" in proceedings of the World Bank Annual Conference on Development Economics Washington, D.C. (1991) 303-304. Leftwich A "Governance, democracy and development" (1993) 4 Third World Quarterly 605-610.

13 UN, note by Secretariat (fn 5 above) 11.

14 Office of the UN High Commissioner for Human Rights 'Good governance practices for the protection of Human Rights' New York (2007) 519. 
intervention. At the core of APRM are the fundamentals of clean government, transparent economic policies and participatory, multi-party democracy. ${ }^{15}$

\section{CORRUPTION: THE ENEMY OF GOOD GOVERNANCE}

The direct opposite or antithesis of good governance is the scourge of corruption, which has been defined by the United Nations as "the abuse of entrusted public power for private benefit". ${ }^{16}$ For the purposes of this paper it is important to emphasise that corruption is a universal problem, "cutting across faiths, religious denominations and political systems." ${ }^{17}$ It is endemic in all governments and is found in democratic and dictatorial politics, feudal, capitalist and socialist economies. It has been aptly described as "a cancer festering within society, enriching a few and impoverishing many". ${ }^{18}$ The corrosive effects of corruption have been well articulated by Mbonu. ${ }^{19}$ However, since one of the segments of this paper is concerned with combating corruption, it is appropriate to highlight the most insidious of these in order to place Botswana's anti-corruption strategies in perspective.

First, in relation to the exercise of state power, corruption weakens the accountability of state officials and reduces transparency in the work of state institutions. Corrupt government officials fail to offer citizens adequate and accurate information about government and policies, curtail the public's opportunities for participation, and violate the public right to be informed about government activities and procedures. ${ }^{20}$

Secondly, corruption is subversive of any country's political system. In the words of John Ashcroft, a former United States Attorney General, "corruption saps the legitimacy of democratic government, and in its extreme forms even threatens democracy itself, because democracy lives on trust, and corruption destroys trust". ${ }^{21}$

Thirdly, corruption is a threat to the rule of law and the administration of justice. 'The implementation of a country's laws as well as efforts to reform them are impeded by corrupt judges, lawyers, prosecutors, police officers, investigators and auditors. In this respect, corruption in the administration of justice compromises the right to equality before the law and the right to a fair trial, undermines the poor's access to justice because they can not afford to offer or promise bribes'. ${ }^{22}$ Furthermore, corruption in any legal system engen-

15 New Partnership for African Development, adopted in October 2001 in Abuja Nigeria, by the National Assembly of the Heads of States and Government Organisations of the Africa Unity. <www. nepad.org.ng>.

16 Boyle B "Holding themselves to a higher standard" Sunday Times 30 April 2006 p 4. The African Peer Review Mechanism Process was adopted at the 6th Summit of the NEPAD Heads of States and Governments, Abuja Nigeria in March 2006. A number of countries such as Ghana, Nigeria and South Africa has subjected themselves to such review.

17 Mbonu C Corruption and its impact on the full enjoyment of human rights, in particular, economic, social and cultural rights E/CN.4/Sub2/2004/23 (7 July 2004) 4.

18 Mbonu (fn 17 above) 4. E/CN.4/Sub2/2003/18 para 4.

19 Mbonu (fn 17 above) 4-7.

20 Office of the UN High Commissioner (fn 9 above) 59.

21 As quoted by Mbonu (fn 17 above) 5 .

22 UN High Commissioner (fn 9 above) 59. 
ders a culture of impunity "since illegal actions are not consistently punished and the country's laws are not consistently upheld". ${ }^{23}$ Mbonu quotes, with approval, this most telling observation on the impact of corruption on the judiciary and law enforcement agencies:

"a corrupt judge is more harmful to the society than a man who runs amuck with a dagger in a crowded street. He can be restrained physically. But a corrupt judge deliberately destroys the moral foundation of a society and causes incalculable distress to individuals through abusing his office, while being referred to as 'Honourable'."24

Fourthly, corruption has a negative impact on the realisation of human rights in that corrupt practices divert funding aimed at social services. In the case of African countries, Mbonu cogently points to "the horrendous depletion of Africa's scarce capital and investible surplus through systematic and official looting of the treasury for corrupt enrichment abroad". ${ }^{25}$ In similar vein, the United Nations High Commissioner For Human Rights underscores the fact that corruption undermines the government's ability to deliver an array of services, including health, education and welfare services. ${ }^{26}$ To return to Mbonu:

'Think of the jobs, the infrastructure, the improved educational system and the enhanced democratic institutions the looted funds could provide if they were redirected from the personal enrichment of the corrupt to the public service of the people. It is widely acknowledged that as a result of the siphoning off of these huge sums from the coffers of the developing countries to developed nations, most of the States have been failed States, unable to perform even ordinary State functions, including providing water, electricity and adequate housing for their populations." ${ }^{27}$

It is instructive to note that corruption is not confined to the public sector. The well-known Enron and Parmalat debacles attest to similar decay in the corporate world. Furthermore it is widely known that multi-national corporations from the developed world often bribe public servants in the countries in which they do business. ${ }^{28}$

\subsection{Strategies to fight corruption}

Because of its debilitating impact on all aspects of life, corruption calls for extraordinary measures to control or eradicate it. The very essence of corruption, which is invariably committed in secrecy, with few witnesses, if any, and between willing participants, means that the normal crime-busting agencies are ill-equipped to deal with it, resulting in the adoption of radical anti-corruption initiatives stressing "openness, transparency, information, competition, sanctions, incentives, clear rules and regulations are strictly enforced". ${ }^{29}$ Other key elements of anti-corruption strategies include unwavering political commitment by the rulers, adequate remuneration for public

24 As quoted by Mbonu. E/CN.4/Sub.2/2005/18 (22 June 2005) 5. Quoting Uwaito J Supreme Court of Nigeria who is known for criticising corruption in the Judiciary.

25 Mbonu (fn 17 above) 4.

26 Office of the UN High Commissioner (fn 9 above) 59.

27 Mbonu (fn 17 above) 7 para 19.

28 Ibid; see reference to Cruver B Enron anatomy of greed (2002) Camoll and Graf Publishers.

29 Mbonu (fn 17 above) 5. 
servants and political leaders, falling under what has come to be known as national integrity systems. At the heart of the national integrity system are key institutions including civil society, watchdog institutions (such as Parliament and the Ombudsman); a free and independent press/media; an independent judiciary, etc. ${ }^{30}$

Among the critical elements in the war against corruption is that of the leadership of the anti-corruption institutions, a matter of seminal importance in the case of Botswana's Directorate on Corruption and Economic Crime, as will be discussed hereunder. Further, since corruption is prosecuted after the event, prevention should be the overarching objective. This, in turn, requires a concerted effort from all sections of society, making it clear that corruption is a "high-risk" and "low-profit undertaking". ${ }^{31}$ The importance of preventive measures is underlined by the United Nations Convention against Corruption, 2003 which requires governments to, inter alia, pass criminal laws against the bribing of their own and foreign officials and other corruption-related acts, such as embezzlement and money-laundering, and to take preventive measures against corruption, facilitate cooperation among states for the purposes of extradition and asset recovery, etc. ${ }^{32}$

\section{MALADMINISTRATION}

The last part of this article deals with Botswana's efforts to address maladministration in government. The point to note here is that neither the courts nor other tribunals can offer a remedy when private citizens complain that public authorities, although they have acted within the law, have failed to observe the proper standard of administrative justice. It is faults of this kind which are often referred to as maladministration. It includes bias, neglect, inattention, inordinate delay, incompetence, ineptitude, perversity, turpitude, capriciousness and arbitrariness, which all call for redress outside the formal, judicial system.

Having established the broad parameters of good governance, corruption and maladministration, it is now apposite to apply these benchmarks to the efforts by the government of Botswana to promote good governance and to curb corruption and maladministration. It must be emphasised that the corruption perception index used by Transparency International is generally accepted as a guide to the prevalence rates of corruption in the countries polled. It is not cast in stone. Similarly, the elements and pillars of national integrity systems are used here as tools of analysis. In an article of this limited scope, our approach is humbler but not, we trust, without value. Thus the power of international capital and the possible manipulation of anti-corruption measures and institutions, well elucidated by Mbonu and the UN High

30 Doig A, Moran J "Anti- corruption agencies: The importance of independence for the effectiveness of national integrity systems" in (ed) Fignuat Corruption and law enforcement The Hague, Kluwer Law International (2002) 229.

31 Doig A (fn 30 above) 223.

32 UN Convention against Corruption, adopted by the General Assembly Resolution 58/4 on 21 October 2003. 
Commissioner for Human Rights, are beyond the scope of this paper. Even in the case of our country study, Botswana, our discussion is confined to those aspects of good governance and combating corruption which relate to our central thesis that cracks are beginning to appear in Botswana's political edifice. ${ }^{33}$

\section{GOOD GOVERNANCE - THE CASE OF BOTSWANA}

Botswana became an independent state on 30 September 1966. The independence Constitution, though tailored on the Westminster parliamentary system, provided for a unified executive with the President combining the ceremonial functions of Head of State and the executive functions as Head of Government. There was a unicameral legislature elected on the basis of universal adult suffrage and an independent judiciary.

Since 1966, Botswana has remained faithful to the ideals of liberal democracy. This was the case even when other English-speaking countries in Africa drifted into one-party dictatorships. In this part of the paper, it is proposed to critique Botswana's record against some of the key benchmarks of good governance adumbrated above.

\subsection{Executive presidentialism}

As observed above, the executive powers of the Republic are vested in the President. These powers and functions are discharged in the President's own deliberative judgment, directly or indirectly, through subordinates. ${ }^{34}$ Although the Constitution provides for the Office of Vice-President and a Cabinet of Ministers, these are essentially advisory bodies. The President may indeed consult the Vice-President and his Ministers but is ultimately not obliged to act in accordance with such advice.

In the context of good governance, it has been argued that the Constitution vests too much power in the Presidency when the holder of that office is not popularly elected. Komboni cites an example where the former President, Mogae, publicly threatened in a Botswana Television news broadcast to dissolve the newly-elected Parliament after the 2004 general elections if the National Assembly did not endorse his choice of Vice-President, with a chilling effect on Members who were not guaranteed re-election. ${ }^{35}$ The overwhelming preponderance of the ruling party over the opposition parties in the National Assembly, coupled with a very strong Presidency, has had the effect of relegating the National Assembly to a rubber-stamp and in the

33 UN High Commissioner for Human Rights "The role of good governance in the promotion of Human Rights" E/CN.4/2005/97 (14 December 2004). See Mbonu C Corruption and its impact on the full enjoyment of human rights in particular, economic, social and cultural rights E/CN4./Sub2/2005/18 (22 June 2005).

34 The Constitution of 1996 s 47.

35 Komboni GG "Good governance in Botswana: Fighting corruption and maladministration" (2005) (as yet unpublished) LLM Dissertation 23. President Mogae retired and handed over power to his vice-president, Lieutenant General Ian Khama 1 April 2008. 
process eroding its constitutional role of oversight over the executive branch of government. ${ }^{36}$

\subsection{Electoral democracy}

Botswana's legislative power is vested in an unicameral legislature, consisting of the President and the National Assembly. The overwhelming majority of the members of the National Assembly are elected under a system based on adult universal suffrage from single-member constituencies, using the "first past the post" system. ${ }^{37}$

In theory the system enables the electorate to elect representatives of their choice to represent them in the National Assembly and also to recall them if not satisfied with their performance. In this respect parliamentary elections have been held regularly, every five years, with the last one being held in 2004. However, a critical appraisal of the electoral system reveals a number of problem areas which can be summarised as follows:

6.2.1 It is true that periodic and free elections have been held every five years since independence. However, the question that keeps arising is that of the fairness of these elections. At the heart of this question is the stark reality that the playing field between the ruling Botswana Democratic Party and other political parties is not even. Apart from the advantages associated with being the party in government, in the absence of political party funding from the state the opposition parties have always been at a considerable disadvantage in mobilising the requisite financial and other resources, including logistics, to mount successful campaigns. ${ }^{38}$ Allegations of misuse of state resources are always common in Africa and Botswana has not escaped that syndrome.

6.2.2 There is also the inherent weakness embedded in the electoral system of "first past the post" which, over the years, has resulted almost invariably in the opposition parties getting fewer and fewer seats in the National Assembly despite their increasing share of the popular vote. In the 2004 elections the opposition parties obtained $22.8 \%$ of the seats (13 seats) despite having garnered $47.25 \%$ of the popular note. In stark contrast, the ruling Botswana Democratic Party obtained $77.2 \%$ of the seats (44 seats) of the 57 seats available, with $50.63 \%$ of the vote. ${ }^{39}$ In effect the votes cast for the opposition parties were wasted votes. It may be time that Botswana reviews its electoral

36 Osei-Hwedie BZ, Sebudubudu D “Botswana's 2004 elections, free and fair” (2005) 41 Journal of African Elections 27-42.

37 The Botswana Constitution (fn 34 above) sections 57 and 86.

38 Osei- Hwedie B (fn 36 above) 27-24,

39 Government of the Republic of Botswana, Independent Electoral Commission, Report of the Minister of Presidential Affairs and Public Administration on 2004 Elections 27-28. 
system, preferably in the direction of proportional representation and multi-member constituencies.

One of the determinants of good governance is representative democracy, anchored on a pluralistic political system. However, in the case of Botswana Osei-Hwedie and Sebudubudu have poignantly observed that "elections in Botswana have become a ritual and routine way of legitimising the ruling party, which is guaranteed to win". In effect Botswana is a one party dominant state. It fails the crucial test of alternation of power. ${ }^{40}$

\subsection{Fidelity to the law and respect for human rights}

Generally, the rule of law in the sense that the exercise of public power should be authorised by the Constitution and the ordinary law of the land, absence of arbitrariness or irrationality in the decision-making processes and equality before the law, prevails in Botswana. The leading case of Unity Dow $v$ The Attorney General ${ }^{41}$ is the leading authority for the proposition that the courts have the power to strike down legislative acts and executive actions repugnant to the Constitution.

In the Dow case Unity Dow, a citizen of Botswana by birth, impugned the constitutionality of sections 4 and 5 of the Citizenship Act of Botswana as being discriminatory against her on the basis of her sex. Dow, who was married to a non-citizen of Botswana, was unable to pass citizenship to her children born and raised in Botswana. The children were foreigners in the land of their birth. The same restriction did not apply to the children of Batswana men married to foreign women. The High Court and the Court of Appeal ruled in favour of Dow. ${ }^{42}$ However, it took three years to bring the Citizenship Act in line with the court's ruling. ${ }^{43}$

It is also generally accepted that Botswana has had a good record in the field of human rights, particularly in terms of respect for and observance of civil and political rights. Section 3 of the Constitution provides:

"Whereas every person in Botswana is entitled to the fundamental rights and freedoms of the individual, that is to say, the right, whatever his race, place of origin, political opinions, colour, creed or sex, but subject to respect for the public interest, to each and all of the following namely:

i) Life, liberty, security of the person and the protection of the law;

ii) Freedom of conscience, of expression and of assembly and association; and

iii) Protection for the privacy of his home and other property and from deprivation of property without compensation."

The general grant is followed by substantive provisions enshrining the traditional civil and political rights modelled on the Universal Declaration of Human Rights, 1948 and the European Convention on Fundamental Human Rights, 1950. It is also instructive to note that the government of Botswana

40 Osei-Hwedie (fn 36 above) 29.

41 (1992) BLR 112.

42 Attorney-General $v$ Unity Dow 1992. The Attorney-General had appealed to the Court of Appeal against the High Court decision in Unity Dow $v$ the Attorney General, but was unsuccessful.

43 The Citizen Act was subsequently amended in 1995. 
has ratified the International Covenant on Civil and Political Rights, the International Convention on the Elimination of All Forms of Racial Discrimination, the Convention on the Elimination of All Forms of Discrimination against Women, the Convention against Torture and Other Cruel, Inhuman or Degrading Treatment or Punishment, the Convention on the Rights of the Child and its Optional Protocol on the Sale of Children, Child Prostitution and Child Pornography, the African Charter on Human and Peoples' Rights and the African Charter on the Rights and Welfare of the Child. However, it has not ratified the International Covenant on Economic, Social and Cultural Rights. ${ }^{44}$ The immediate and direct consequences of non-ratification and domestication of this Covenant is that Government is not under an international law obligation to take positive steps to promote and fulfil the rights of its people in the field of socio-economic development. ${ }^{45}$ Other problem areas may be summarised as follows:

6.3.1 The challenge of ensuring "an equitable and homogeneous distribution of wealth and services" as well as ensuring the protection and enjoyment of human rights of the indigenous population of the country - the Basarwa/San communities. The Committee on the Elimination of Racial Discrimination stated at its sixty-first session that "the cultural and linguistic rights of the Basarwa/San are not fully respected, especially in educational curriculum and in terms of access to media". ${ }^{46}$

6.3.2 Participation in the House of Chiefs, currently enjoyed by the so-called main "tribes". The House of Chiefs is a body of traditional leaders which advises parliament on any matter of national concern. They are particularly consulted on issues that are likely to impact on their culture and traditions. Representation in the House of Chiefs mirrors, in some ways, the territorial demarcation of the country in terms of the dominant "tribes" occupying them. Minority tribes argue that their Chiefs should be represented in the House of Chiefs so that they can be consulted on matters affecting their lives. In 2000, the government appointed a Commission of Enquiry to review laws, including sections 77, 78 and 79 of the Constitution that were considered discriminatory against minority tribes. A Bill amending these sections was tabled

44 United Nations, Economic and Social Council, Commission on Human Rights Sixty-second sessions Report of the Special Rapporteur on the Right to Education, Vernor Munoz ECN.4/2006/45/ Add.1 (17 March 2006) 7-8.

45 Limburg Principles on the Implementation of the International Covenant on Economic, Social and Cultural Rights, E/CN4/1987/17; see "The Maastricht Guidelines on Violations of Economic, Social and Cultural Rights" (1998) 20 Human Rights Quarterly 691-704. Among the recommendations by the United Nations' Economic and Social Council, Ibid (fn 44 above) is that Botswana should be encouraged to ratify the International Convention to Economic, Social and Cultural Rights as soon as possible as a way of strengthening its commitment to agenda for development 20.

46 As quoted by Munos (fn 44 above). Noting from A/57/18 para 305. See Jefferis J "Botswana and diamond dependant development" Botswana Politics and Society, Edge and Lekrwe (eds) (1998); Kwaku Osei Hwedie, Mufune "Debt relief initiative and poverty alleviation: Lessons from Africa" Pretoria Africa Institute (2003) 
before Parliament but not enacted. At the time of writing the necessary amendments were still in the pipeline. ${ }^{47}$

\subsection{The case of forced removals of the "First People of the Kalahari"}

Botswana's record on respect for the rights of minorities was thrust into sharper relief in the case of Roy Sesana, Keiwa Setlhobogwa And Others $v$ The Attorney-General. ${ }^{48}$ This case is germane to our discussion because one of the key aspects of good governance is popular participation in decision-making processes, direct or indirectly through legitimate intermediate institutions or representatives, in the process ensuring that the concerns of the most vulnerable in society are taken into account. Thus, without the full participation and informed consent of the First People of the Kalahari in the planning, implementation, benefit-sharing and evaluation of development policies and projects, there can be no genuine development of the people concerned, in this case the indigenous people of the Kalahari.

It was common cause that the Central Kalahari Game Reserve was established in 1961 with a view to protecting the wildlife resources and providing sufficient land for traditional use by the resident communities. Whereas the original residents in the Reserve were hunters-gatherers, their lives and settlement patterns had been changing over time to include arable, pastoral agricultural and other commercial activities, inconsistent with wildlife conservation and preservation. Faced with this dilemma, the government of Botswana appointed a fact-finding mission to investigate the situation in the Reserve with a view to providing information that would facilitate decisionmaking on environmental protection and wildlife conservation on the one hand and the socio-economic development of the community on the other. ${ }^{49}$

The findings of this fact-finding mission were to the effect that human settlements in the Reserve were rapidly evolving into permanent, settled agricultural communities and that the residents had largely abandoned their traditional way of life. The government thereafter adopted a new settlement policy providing, inter alia, that the social and economic development of human settlements in the Reserve be frozen as the settlements had no prospect of becoming economically viable and that viable sites for economic and social development be identified outside the Reserve to which residents

47 United Nations, Committee on the Elimination of Racial Discrimination. Sixty-Eight session 20 February - 10 March 2006. CERD/C/BWN/10/16, (4 April 2006). The Committee noted in particular Botswana's reluctance to recognise the existence of indigenous people on its territory (at page 3) with reference to the case of Kamanakao I and Other v Attorney-General 2001 (2) BLR 654(HC). The Committee noted with concern that Botswana had not yet amended the Chieftainship Act and other laws where necessary, as ordered by the High Court. The Committee reiterated its recommendation to Botswana that it amend the Territories Act, in order to remove the discriminatory character against non-Tswana ethnic groups and in order to provide equal protection and treatment to all tribes 5 .

48 Roy Senana et al $v$ the Attorney General Misc No52/2002 delivered on 13 December 2006.

49 The Central Kalahari Game Reserve was established under the High Commissioner Notice No 33 of 1961. See also CCPR/C/BWA/1 (2 May 2007); CERD /C495 dated 2 September 2005 4-38. 
in the Reserve would be encouraged, but not forced, to relocate. ${ }^{50}$ At the end of the exercise, over 2000 residents were relocated out of the Reserve. The remaining residents were informed that the government would no longer provide essential services, including water, to them and that they had to move out. ${ }^{51}$ At the heart of the litigation were the lawfulness and constitutionality of the government's decision to terminate the supply of these essential services, the forcible deprivation of land which they had occupied for thousands of years and the government's refusal to issue special game licenses to the settlers. ${ }^{52}$

On the part of the government it was argued that the government had acted within its rights by removing the residents of the Reserve in the interest of nature conservation, tourism and development and that the residents had in fact been consulted and had consented to the relocation. ${ }^{53}$

Judgment in the case was delivered on 13 December 2006. The Court found for the applicants on two issues but non-suited them on two others. The full bench of three judges agreed that the forcible deprivation of the applicants' land rights in the Reserve which they had lawfully occupied for thousands of years was unlawful and that the government had acted wrongly in stopping subsistence hunting licenses and also in not allowing the residents to enter the Reserve without special game licenses.

The two cases of Kamanakao and Roy Sesana are central to our discussion on good governance because human rights are inextricably linked with democratic governance and because democracy, the rule of law and respect for human rights are indivisible and interdependent. As Justice Dow correctly observed, the "Basarwa in particular and the Bakgalagadi to some extent, as ethnic groups have historically been at the lower end of the social, economic and political social strata and ... until recently ... they were politically silent, a politically voiceless minority." 54

It would appear to us that the government of Botswana has been heavyhanded in the treatment of its ethnic minorities. Even after the High Court partially ruled in favour of the applicants the government still insisted that only

"the 189 surviving original applicants along with their children could return to the Reserve, that essential services would not be restored, that the residents would only be allowed to bring into the Reserve a reasonable amount of water, that domestic animals could not be brought into the Reserve and that people choosing to return to the Reserve would still need to apply to the Department of Wildlife and National Parks for Special Game Licenses." ${ }^{5}$

These issues call for further study and need not detain us here.

50 Ministry of Commerce and Industry, Circular 1 of 1986. See Hitchcock RK "Bushmen and the politics of Environment in South Africa", Copenhagen IWGIA Document No 79 (1996)

51 IWGIA, "Indigenous World Report" Copenhagen (2007) 539-552.

52 See in particular Justice Dibotelo's judgement.

53 Ibid; see also IWGIA (fn51 above).

54 Dow J (fn 41 above) 255-6.

55 IWGIA (fn 51 above) 544-545. 


\subsection{Press freedom}

According to the UN High Commissioner for Human Rights, democracy relies on, inter alia, transparency and accountability. ${ }^{56}$ A vital cog in promoting probity and openness in government is a free and independent press, alert to ferret out corruption and to keep the public informed, especially on matters of interest to the general public. In the case of Botswana, it is generally accepted that although an independent press, largely the print media, has thrived, there have been some worrying trends in recent years resulting in a culture of self-censorship, in both the public and private sectors. ${ }^{57}$

It is perhaps ironic that Good, a persistent critic of the government, was himself declared an "undesirable inhabitant" of Botswana, resulting in his dramatic and unprecedented deportation from the country. Good, an Australian national resident in Botswana for over ten years, lost an application before the High Court in which he sought to challenge the President's decision to deport him from Botswana. The High Court also upheld the constitutionality of a law which ousts the jurisdiction of the High Court from challenging such Presidential decrees. ${ }^{58}$

This deference to the executive by the judiciary has been noted with concern by the United Nations Committee on the Elimination of Racial Discrimination, recommending instead that prohibited immigrants be granted effective remedies before courts of law. ${ }^{59}$

It is submitted that incidents of threats to the independence of the press and to free speech in general peaked at the height of corruption scandals in the late 1990s. They were few and far in between and, therefore, should not sully the country's reputation in that regard.

\subsection{Combating corruption}

In section 4 of this article we articulated the nature of corruption and its corrosive effect on the moral fiber, political and economic well-being of societies. We also identified the array of strategies available to countries in response to the evils associated with corruption. It is now apposite to relate that discussion to our case study of Botswana.

In the introduction to this paper, we pointed out that in the period immediately following the attainment of independence the level of corruption in Botswana was almost negligible. However, the country's "economic miracle" could also be viewed as a curse. The booming economy provided a fertile ground for corruption opportunities to emerge in the multi-billion pula ${ }^{60}$ capi-

56 UN High Commissioner (fn 9 above)9.

57 Good (fn 2 above) 512-513; see Good K Diamonds, democracy and presidentialism in Botswana” in Matlosa $\mathrm{K}$ et al "Challenges of conflict, democracy and development in Africa Johannesburg EISA (2007) 101-120.

58 Kenneth Good $v$ the Attorney General Misc App. 90/2005.

59 CERD Report (fn 47 above) 9.

60 Botswana's national currency is the Pula. As at the beginning of April 20081 pula was the equivalent to R1.21 (South African Rand). 
tal projects such as the development of roads, schools, government offices, public sector housing as well as public procurement.

The earliest reported cases of corruption were exposed through three Presidential Commissions of Inquiry between 1991-1992. The first Commission dealt with the procurement of school books and materials for primary schools for the 1990 school year. This Commission concluded that the winning tender was awarded fraudulently to an inexperienced company, resulting in a loss of the government of P27,000.000. ${ }^{61}$ The second Commission investigated land problems in Mogoditshane and other peri-urban villages near Gaborone, the capital city. It concluded that fraudulent land deals were made by officials under pressure from influential and powerful personalities. ${ }^{62}$

The third Commission of Inquiry was concerned with the operations of the Botswana Housing Corporation, a parastatal company. This Commission also revealed corrupt tendering practices involving collusion between Board members, a government Minister, top management of the Corporation on the one hand and construction companies on the other. ${ }^{63}$

The Commissions of Inquiry also revealed that corruption in Botswana was essentially perpetrated by the elite. This is, however, not to say that there was no corruption at the lower levels of society. In fact, a casual glance through the reports of the Directorate on Corruption and Economic Crime reveals that a lot of cases involve small amounts of money wherein junior officers such as police constables, clerks, teachers and the like have been charged and convicted.

Over the last several years, according to the Transparency International Corruption Perception Index for 2003, Botswana scored 5.7, making it the least corrupt state in Africa; in 2004 Botswana was placed at 6.0; 5.9 in 2005 and 5.6 in $2006 .{ }^{64}$ These general trends support the view that corruption persists but it is not endemic. Interestingly, as poignantly observed by one Kenyan judge, "corruption always fights back". ${ }^{65}$

It has begun to rear its ugly head again. To illustrate, in $\mathrm{S} v$ Elridge Mhlauli a former Permanent Secretary was charged and convicted on corruption charges involving the allocation of land housing the "River Walk Mall" in Gaborone. At the time of writing Mhlauli was appealing againts both conviction and sentence. ${ }^{66}$ Even more startling is the matter of $S v$ Louis Nchindo, a former Managing Director of Debswana, the giant diamond mining conglamorate jointly owned by the government of Botswana and De Beers. Despite being the Chief Executive of a key conglomorate, Nchindo was accused of acquiring

61 Report of the Presidential Commission of Inquiry into the Supply of School Books and Materials in Primary Schools for the 1990 School Year, Gaborone 1991.

62 Report of the Presidential Commission of Inquiry into Land Problem [mes] in Mogoditsane and other peri-urban villages near Gaborone, Government Printers 1991.

63 Report of the Presidential Commission of Inquiry into the Operations of the Botswana Housing Corporation, Gaborone; Government Printers, 1992

64 Transparency International "Corruption Perception Index" accessed on 18 January 2007.

65 Mbonu (fn17 above) 15.

66 Courtesy of attorney PJ Ngandwa, DPP's Chambers, Gaborone, 3 September 2007 (as yet unreported). 
land in Gaborone ostensibly in the context of the company's diversification project when in fact he acquired it for his own personal benefit. Apparently the former State President, Festus Mogae, had endorsed the transaction but claimed that he was not aware of any improprieties. ${ }^{67}$

\subsubsection{Anti-corruption legislation}

The Government of Botswana responded to the earlier incidents of corruption by enacting the Corruption and Economic Crimes Act, $1994 .{ }^{68}$ Under the Act, a Directorate on Corruption and Economic Crime was created. Broadly, the functions of the Directorate, as stated in section 6 of the Act, involve three aspects, namely:

- Investigation of corruption;

- Prevention of corruption; and

- Education of the public on the dangers of corruption.

There are a number of problem areas with Botswana's anti-corruption regime. They can be summarised thus:

\section{(a) Nature of the anti-corruption agency}

Section 3 of the Act establishes the Directorate as a public office subject to the provisions of the Public Service Act. The Directorate is under the Office of the President and the Director is formally and directly responsible to the President. It is submitted that this arrangement compromises the institutional autonomy of the Directorate, contrary to international best practice which requires anti-corruption agencies to be functionally and institutionally independent. ${ }^{69}$

(i) The head of the Directorate, the Director, is appointed by the President in his/her own deliberative judgment, without consultation with non-partisan agencies such as the Judicial Service Commission.

(ii) As the Directorate is part of the Public Service, the Director and his subordinates are accountable to the Head of the Public Service, who is the Permanent Secretary to the President. This means that the Director and his staff are supervised by the Permanent Secretary to the President, at least administratively. Furthermore, the terms and conditions of service, assessment of salaries, gradings, discipline and other human resource matters are in terms of the Public Service Act, the responsibility of the Director of Public Service Management, further compromising the institutional autonomy of the Directorate. ${ }^{70}$

67 Ibid (fn 66 above); Cohen L "Disgraced diamond boss's posh South African refugee” Sunday Times (13 April 2005) 9.

68 Corruption and Economic Act Cap 08:05 of the laws of Botswana.

69 Doig, Moran (fn 30 above); UN High Commissioner (fn 9 above) 66. It is also argued that this arrangement allows the political leadership to support the Directorate's work and puts the drive against corruption high on the country' political agenda.

70 Public Service Act, Cap 26:01 of the laws of Botswana. 
(iii) One of the determinants of independence of the anti-corruption agency is the manner of appointment of its head, his/her security of tenure etc. Section 4 of the Act empowers the President to appoint the Director "on such terms and conditions as he sees fit". The Act is silent on the question of security of tenure. Without such security, the Director would naturally be slow to institute investigations into well-connected and highly-placed people. He/she cannot be expected to carry out his/her functions without fear or favour. It is therefore recommended that the parent Act be amended so as to provide for Presidential consultation with non-partisan agencies such as the Judicial Service Commission or a Select Committee of the National Assembly. The operational independence and security of tenure should also be expressly guaranteed so that, for example, removal from office should be made similar to that of judges of the High Court; that is, only for serious misconduct and only upon credible investigation of such misconduct by an independent and impartial tribunal.

\section{(b) Investigation of Corruption}

One of the key functions of the Directorate is to receive and investigate any complaints alleging corruption in any public body. ${ }^{71} \mathrm{~A}$ public body is defined as "any office, organization, establishment or body created by or under any enactment or under powers conferred by any enactment, and includes any company in which 51 per cent or more of the equity shares are owned by the Government of Botswana”.

The import of section $6(\mathrm{a})$ is that the Directorate has no jurisdiction in matters of corruption which takes place in private companies. A good example, excluded from the reach of the law, is Debswana Diamond Mining Company in which the Government has a 50/50 shareholding with De Beers. Debswana is by far the most important company in Botswana's economy. It is the only company that currently mines Botswana's rich diamond deposits. Diamonds are the mainstay of the economy. Debswana is involved in procurement and construction projects worth millions of Pula annually. ${ }^{72}$ It is trite that procurement and construction activities provide fertile grounds for corruption. The law, therefore, needs to be changed to cover corruption in the private sector in line with article 12(1) of the UN Convention Against Corruption which demands that

\footnotetext{
"[e]ach state party shall take measures, in accordance with the fundamental principles of its domestic law, to prevent corruption involving the private sector and where appropriate provide effective, proportionate and dissuasive civil, administrative or criminal penalties for failure to comply with such measures."73
}

In similar vein, the SADC Protocol Against Corruption, of which Botswana was the first country to sign, in articles 1 and 3, extends the law on corruption

\footnotetext{
71 Public Service Act (fn 70 above) s6.

72 See the Louis Nchindo case (fn 67 above).

73 The United Nation Convention against Corruption (fn 32 above) article 12(1).
} 
to private entities. It would therefore, be fitting for the Act to be amended accordingly to cover corruption in the private sector.

\section{(c) Corruption prevention}

One of the pillars of the national integrity system is public awareness and participation in the "war on corruption". Our interaction with the Directorate has revealed that the Directorate has been proactive in raising public awareness about the dangers of corruption, including the provision of management advisory services and public education campaigns about zero-tolerance for corruption involving talk-shows and presentations in different localities in the country. The Directorate has reached out to schools, the University of Botswana, government ministries, cooperatives and voluntary organisations such as trade unions and chambers. However, the efficacy of these campaigns has been limited and "petty corruption has persisted". ${ }^{74}$

\section{(d) Prosecution of offences}

Section 6 of the Act empowers the Directorate to investigate allegations of corruption. At the conclusion of the investigation, if there is evidence of corruption, the Director is enjoined to refer the matter to the Attorney-General who is vested with the power to initiate or discontinue criminal prosecutions. ${ }^{75}$ This referral system has inevitably resulted in inordinate delays and inefficiencies in the anti-corruption effort. ${ }^{76}$ To obviate these problems, the powers of the Attorney-General need to be delegated to the Directorate so that prosecutors from that Directorate could initiate prosecutions. It is very important for the well-being and credibility of the anti-corruption regime that corrupt practices are investigated promptly and those with cases to answer charged and tried within a reasonable time.

\section{(e) Protection of informers and whistle blowers}

A successful strategy to combat corruption also requires a climate which is conducive to the disclosure of information by employees relating to corrupt practices in the workplace. Section 45 of the Act provides some limited protection in that a witness is not obliged to disclose the name and address of any informer or state any matter which might lead to the discovery of the witnesse's identity. It is recommended that appropriate legislation be enacted along the lines of the South African Protected Disclosure Act, 2000 to protect informers and whistle blowers from reprisals.

The last point to be made about the anti-corruption regime in Botswana is that there is a perception that the Directorate has not investigated and prosecuted any big fish since its inception, lending weight to the old adage that justice is like a spider's cobweb where small flies get caught and the big

\footnotetext{
74 Komboni (fn 35 above) 42-43; also see DCEC, Annual Reports (2001-2002) 23-26, (2003-2004) 24-31, 43-49, 84-85.

75 Anti Corruption Act (fn 68 above) s39.

76 DCEC Annual Report (2002, 2003-2004).
} 
villains go through unscathed. It is appropriate to conclude our discussion by looking at the specific measures to redress maladministration.

\section{REDRESS OF MALADMINISTRATION}

It is paradox that, although Botswana was always known for its good record on governance, it did not have a dedicated institution to deal with cases of injustice and maladministration. This is despite the fact that there have been calls for the establishment of the office of Ombudsman since the 1970s. The 1982 Presidential Commission of Economic Opportunities also recommended the establishment of an office of a 'Public Commissioner' to address complaints of inefficiency, delay, malpractices or government officialdom.

As pointed out in the preceding section, the corruption scandals in the early 1990s showed that ordinary law-enforcement agencies were ill-suited to deal with incidents of maladministration or bad governance. The Office of the Ombudsman was thus created to meet a new felt need to complement existing institutions and to resolve complaints of maladministration speedily, informally and inexpensively. ${ }^{77}$ The mission of the Office of the Ombudsman is to protect members of the public against acts of maladministration in the public sector and advocate the upliftment of human rights in an independent and impartial manner. ${ }^{78}$

The Office of the Ombudsman was established under the Ombudsman Act of $1995 .{ }^{79}$ The Ombudsman is appointed by the President, after consultation with the Leader of the Opposition in the National Assembly. Once appointed, he or she holds office for a relatively short period of four years. The Act is not clear whether the term is renewable. Section 2(6) of the Act, as read with section 97 of the Constitution, gives the Ombudsman security of tenure in that he/she can only be removed from office under the same procedures applicable to the judges of the High Court.

Broadly, the Ombudsman is empowered to receive and investigate complaints of injustice and maladministration in the public service, received from the public (including bodies corporate) and if such complaints are valid, to make recommendations to the appropriate authority for compliance. A close reading of the enabling legislation reveals shortcomings which call for review.

First, the Office of the Ombudsman is an essential cog in the National Integrity System. International best practice therefore sees the Ombudsman as an Officer of Parliament who reports to Parliament generally on an annual basis. In Botswana the Ombudsman reports to Parliament through the President. None of his or her reports are debated in the National Assembly.

77 Ayeni V, and Sharma K Ombudsman in Botswana (eds) London (2000).

78 Office of the Ombudsman, Annual Report (2003-2004). The vision of the office is stated as to be "the leading institution in the promotion of good governance, best practices and respect for human rights".

79 Act 5 of 1995; see (fn 78 above). 
Under section $8(1)$ of the Act, the Ombudsman's primary function is to investigate allegations of maladministration and then send a report of the results of the investigation to the principal officer of the department or authority concerned. If no remedial action is taken within a reasonable time which appears adequate to remedy the injustice, the Ombudsman may lay before the National Assembly a special report. This must be done by the Minister. The law is silent as to what is to be done if the Minister fails or refuses to lay the report before the National Assembly.

Komboni $^{80}$ cites the issue of the former Vice-President and recently installed President, General Khama, to illustrate the weakness of the law regarding the Ombudsman's linkage with Parliament. In 2000, the Ombudsman investigated complaints from the Botswana Congress Party on alleged irregularities involving public officers accompanying the then Vice-President on party political activities of the ruling Botswana Democratic Party. He investigated this complaint together with other public concerns about the then Vice-President flying military aircraft when he was no longer a member of the Botswana Defence Force.

At the end of the investigations, the Ombudsman recommended that public servants should not accompany the then Vice-President to his political rallies and that it was inappropriate for the then Vice-President to continue flying military aircraft when he was no longer in the Botswana Defence Force.

These recommendations seem not to have been complied with. In his Annual Report for 2001/2002 the Ombudsman lamented that twenty-six months had gone by following submission of his report and no response had been received. ${ }^{81}$ Because of non-compliance with his report, the Ombudsman invoked section $8(2)$ of the enabling Act which empowers him to lay a Special Report before the National Assembly if no action was taken within a reasonable time. This Special Report has to go through the Minister for Presidential Affairs. As late as 2005 this Special Report itself had not been tabled before the National Assembly. In an interview on 26 January 2005, the Ombudsman was of the view that non-compliance with his recommendations was a very poor reflection on good governance because if the leadership does not lead by example, it sent a poor signal to the rest of the civil service that the Ombudsman was a non-entity. Non-compliance touched the very heart of the institution. ${ }^{82}$

It is respectfully submitted that the issue of the then Vice-President amply demonstrates the need for clear relationship between the Ombudsman and the National Assembly. It also underscores the need to de-link the Office of the Ombudsman from the Presidency.

Secondly, one of the pillars or essential attributes of the Ombudsman institution is that of protection against arbitrary removal from office and that the term of office should be long enough to guarantee the independence of that

\footnotetext{
80 Komboni (fn 35 above) 88-89.

81 Office of the Ombudsman (fn 78 above) (2001-2002).

82 Komboni (fn 35 above) 90.
} 
office. In Botswana, the Ombudsman holds office for a term of four years. The Act is silent on the possibility of renewal. It is respectfully submitted that the term of four years is rather too short to guarantee the functional independence of an incumbent Ombudsman. The four years may end before a pending investigation can be finalised. It is therefore recommended that a longer term of office is desirable, for example, a non-renewable term of seven years as is the case with the Public Protector in the Republic of South Africa. ${ }^{83}$

Thirdly, sections 3 and 4 of the Act dealing with the jurisdiction of the Ombudsman are also problematic. Section 3(1) states that the Ombudsman can investigate action taken on behalf of a government department or "other authorities". This has resulted in instances where some organisations which the Ombudsman tried to investigate questioned his competence to investigate them. ${ }^{84}$

Fourthly, section 2(a) and (b) read with section 4(i) show that the Ombudsman cannot investigate a complaint wherein the aggrieved person has the right to be heard by a tribunal or a court of law or a complaint which may be enquired into by a court of law. The High Court of Botswana has an unlimited jurisdiction to hear any matter regardless of the jurisdiction of other courts or tribunals. A strict reading of these sections leads to the irresistible conclusion that the Ombudsman has nothing to investigate. It is therefore important that the Act be revisited to remove these ambiguities and absurdities.

Fifthly, it would appear that sections 3(1) and 3(3) suggest that the Ombudsman cannot investigate human rights violations insofar as they relate to maladministration. It is respectfully submitted that the Act be amended so as to give the Ombudsman the competence to investigate human rights violations resulting from maladministration.

Finally, the Ombudsman is also excluded from investigating complaints of maladministration relating to human resource matters in the public service as well as those arising from contractual undertakings between the government and members of the public. As pointed out under section 4 of this article, public procurement is one of the fertile grounds for corruption. Maladministration often arises out of contracts between the government and individual suppliers (corporate and natural entities). These areas require law reform.

\section{CONCLUSION}

This article has been concerned with the legal and institutional arrangements to promote good governance and combat the twin evils of corruption and maladministration in Botswana. This has been done within a contextual framework in which clearly established benchmarks or parameters have been used as tools of analysis. Consequently the article has identified areas

83 Constitution of the Republic of South Africa (fn 34 above) s181.

84 Komboni (fn 35 above) $79-94$. 
of concern with regard to good governance, namely the preponderance of a very strong executive vis-a-vis the legislature, the one-party dominant system of electoral democracy and the reluctance of the government to repeal discriminatory laws against minority ethnic groups, especially the indigenous people of the Kalahari.

The article also concludes that, although corruption is not endemic in Botswana no country can afford to be complacent. The article therefore recommends legislative reform aimed at strengthening the Directorate on Corruption and Economic Crime so as to be in line with international best practice. The Director of the anti-corruption agency and the Ombudsman should report to Parliament and not to the executive.

\section{BIBLIOGRAPHY}

Ayeni V and Sharma K (eds) Ombudsman in Botswana, selected papers cases and materials London: Commonwealth Secretariat (2002).

Court J et al Making sense of Governance: Empirical Evidence From Sixteen Transitional societies London: Lynne Rienner (2004).

Doig A and Moran J "Anti-corruption Agencies: The Importance of Independence and the effectiveness of National Integrity Systems", in Corruption and Law Enforcement (2002).

Doig A and Riley S "Corruption and Anti-Corruption Strategies: Issues and case studies from Developing Countries", in Integrity Improvement Initiatives in Developing Countries (New York; United Nations Development Programme) (1998).

Edge W and Lekorwe (eds). Botswana, Politics and society, Pretoria: JL van Schaik Publishers (1998).

Fignaut C, Heurbert Corruption, Integrity and Law Enforcement The Hague: Kluwer Law International (2002).

Fombad CM "Curbing Corruption in Africa: some lessons from Botswana's experience” International Social Science Journal, Vol 51. No 160. Pp241-254 (1999).

Good K "Corruption and Mismanagement in Botswana: a best-case example", (1994) The Journal of Modern African Studies Vol 32. No 3. pp499-521.

Good K "Diamonds, democracy and presidentialism in Botswana" in Matlosa $\mathrm{K}$ et al Challenges of Conflict, Democracy and Development in Africa Johannesburg ELSA (2007).

Good K and Taylor I "Presidential Succession in Botswana: No Model for Africa” Unpublished mimeo, 23 February 2005

Hitchcock RK Bushmen and The Politics of the Environment in Southern Africa Copenhagen: IWIGIA Document No 79 (1996).

Landell-Mills P and Serageldin L "Governance and the External Factor" in Proceedings of the World Bank Annual Conference on Development Economics World Bank Washington D.C (1991). 
Leftwich A “Governance Democracy and Development”, Third World Quarterly Vol 14. No. 3 (1993).

Matlosa K et al Challenges of Conflict Democracy and Development in Africa Johannesburg, ELSA (2007).

Mulinge MM and Mufune P Debt Relief Initiatives and Poverty Alleviation: Lessons from Africa. Pretoria, Africa Institute (2003).

Theobald C "The World Bank: Good Governance and the New Institutional Economics", Law and State. Vol 59/60 (1999).

Tordoff W Governance and Politics in Africa London: Macmillan Press (1997).

Osei-Hwedie, B and Sebudubudu D “Botswana's 2004 Elections, Free and Fair” Journal of African Elections Vol 4. No. 1 pp27-42 (2005).

United Nations Secretariat "The Right to Development: Study on Existing bilateral and multilateral programmes and policies for development partnership" E/CN.4/sub.2/2004/15.

United Nations, Economic and Social Council, "The role of good governance in the promotion of human rights", E/CN.4/2005/97.

United Nations, Economic and Social Council, "Interdependence Between democracy and human rights", E/CN.4/2005/58.

United Nations, Economic and Social Council, "The Right to Education", Report of the Special Rapporteur, Vernor Munoz, Mission to Botswana. E/CN.4/2006/45/Add.1.

United Nations, Economic and Social Council, "Corruption and its Impact on the full enjoyment of human rights, in particular, economic, social and cultural rights", Preliminary report of the Special Rapporteur, Ms Christy Mbonu. E/CN.4/Sub.2/2004/23.

United Nations, Economic and Social Council, "Corruption and its impact on the full enjoyment of human rights, in particular, economic, social and cultural rights", Progress report submitted by the Special Rapporteur, Ms Christy Mbonu, E/CN.4/Sub.2/2005/18.

United Nations, Office of the United Nations High Commissioner for Human Rights, Good Governance Practices for the Protection of Human Rights, New York, 2007.

United Nations, Office on Drugs and Crime, "Background and Highlights to the U.N. Convention against Corruption”, file://c:/document i/ADMIN-1/10 Caisu/Temp/3 p162 J18. 2006/08/07.

World Bank, Report on Africa, Washington, D.C. 1989. 